\title{
Chemical properties and rates of external color of strawberry fruits grown using nitrogen and potassium fertigation
}

\author{
Propiedades químicas e índices de coloración externa de frutos de fresa cultivada \\ bajo la fertirrigación con nitrógeno y potasio \\ Cleber Lázaro Rodas ${ }^{1 *}$, Inêz Pereira da Silva ${ }^{1}$, Viviane Amaral Toledo Coelho ${ }^{1}$, \\ Diogo Monteiro Guimarães Ferreira ${ }^{2}$, Rovilson José de Souza ${ }^{3}$, Janice Guedes de Carvalho ${ }^{1}$
}

\begin{abstract}
Strawberry crop is part of the world market as an important alternative to agricultural diversification. The mineral nutrition is closely related to production quality, but there are some questions on plant nutrition and strawberry fruit quality relationship. Thus, studies related to strawberry plants mineral nutrition contribute to a better understanding about this crop. In this sense, the current study aimed to evaluate the effects of nitrogen and potassium fertigation in strawberry crop under field conditions on chemical properties and fruit external color rates. The experiment was carried out at UFLA, Lavras, MG, Brazil, using a randomized blocks experimental design, replicated three times, in a $4 \mathrm{x} 4$ factorial scheme. Four nitrogen doses $\left(100,200,300\right.$ and $\left.400 \mathrm{~kg} \mathrm{ha}^{-1}\right)$ and four potassium doses $\left(150,300,450\right.$ and $600 \mathrm{~kg} \mathrm{ha}^{-1}$ of $\left.\mathrm{K}_{2} \mathrm{O}\right)$ were applied using urea and potassium chloride as respectively sources of nutrients. Strawberry plants from cultivar Aromas were used. Our results shown that strawberry fruit chemical properties and fruit external color rates are influenced by both, nitrogen and potassium fertigation, varying according to the studied property.
\end{abstract}

Key words: Fragaria x ananassa Duch., mineral nutrition, fertilization, fruit quality.

\section{RESUMEN}

El cultivo de la fresa entra en el mercado mundial como una importante alternativa para la diversificación agrícola, siendo la nutrición mineral estrechamente relacionada con la calidad de la producción; sin embargo, todavía hay muchas preguntas acerca de la relación entre la nutrición de plantas y la calidad de la fresa. Por lo tanto, los estudios relacionados con la nutrición mineral de fresa van a contribuir a una mejor comprensión de ese cultivo. En este sentido, el presente estudio tuvo como objetivo evaluar el efecto del nitrógeno y potasio en fertirrigación en la fresa, bajo condiciones de campo, con respecto a las propiedades químicas y los índices de color externo de la fruta. El experimento se llevó a cabo en la Universidad Federal de Lavras, Lavras, MG, Brasil. Se utilizó un diseño de bloques completos al azar con tres bloques y 16 tratamientos en un factorial $4 x 4$, cuatro niveles de nitrógeno $\left(100,200,300\right.$ y $\left.400 \mathrm{~kg} \mathrm{ha}^{-1}\right)$ y cuatro niveles de potasio $\left(150,300,450\right.$ y $600 \mathrm{~kg} \mathrm{ha}^{-1}$ de $\left.\mathrm{K}_{2} \mathrm{O}\right)$, utilizando como fuentes de estos nutrientes, urea y cloruro de potasio, respectivamente. Utilizamos las plántulas del cultivar de fresa Aromas. Las propiedades químicas y los índices de coloración externa de frutas de fresa se ven influidas por la fertirrigación de nitrógeno y potasio, que varían según la propiedad estudiada.

Palabras clave: Fragaria x ananassa Duch., nutrición mineral, fertilización, calidad del fruto.

\section{Introduction}

Strawberry crop (Fragaria x ananassa Duch.) occurs in almost all over the world. Its unique flavor makes it one of the most popular summer fruits (Recamales et al., 2007). According to FAO (2010) the cultivated area of this plant in the world in 2009 was approximately 253.900 ha and the total annual production in that year was 4.1 million tons.
As for the quality, the taste of strawberry is one of the most important aspects. The sweet taste of this fruit is conditioned, in part, by the balance of sugar and acidity in fruit (Brackmann et al., 2002). The total soluble sugars in fruits are carbohydrates of low molecular weight. They are the most soluble solids of strawberries and are related with sweetness, flavor, aroma, attractive color and texture (Lima, 1999).

1 Departamento de Ciência do Solo, Campus Universidade Federal de Lavras, Caixa Postal 3037, 37200-000, Lavras-MG, *cleberrodas@yahoo.com.br

2 Departamento de Ciências Naturais/UFSJ.

3 Departamento de Agricultura/UFLA.

Fecha de Recepción: 05 Noviembre, 2011.

Fecha de Aceptación: 10 Octubre, 2012. 
In the sensory attribute of appearance, color is the quality factor that more attracts the consumers. The strawberry attractive color is due to the presence of anthocyanins, which are natural pigments derived from sugars. The presence of this pigment is an indicator of fruit maturation (Flores Cantillano, 2003). Chitarra \& Chitarra (2005) report that heavy fertilization with nitrogen affects the color of some fruits.

The mineral nutrition, as well as the cultivar, climatic conditions, agronomic practices and water supply, directly influences the quality of strawberry (Nestby et al., 2004).

Among the nutrients, nitrogen stands out. Its adequate supply improves the physical and chemical characteristics of the fruit. Potassium, known as the quality nutrient, is also noteworthy due to its important effect on the size, shape, color, flavor and storage strength of vegetables (Chitarra \& Chitarra, 2005).

Nitrogen is often applied in high amounts in strawberry crop. Producers, aim high yields, but the lack of technical information on the use and management of this fertilizer in this culture raises the production costs and causes serious problems of environmental contamination by the leakage of nitrogen, primarily in the form of nitrate (CárdenasNavarro et al., 2004; Vázquez-Galvez et al. 2008).

The fertigation technique is an excellent alternative that maximizes productivity while minimizes environmental damages (Hagin et al., 2002), by increasing the fertilizer use efficiency (Kafkafi \& Tarchitzky, 2011).

In this sense, the current study aimed to evaluate the effects of nitrogen and potassium fertigation in strawberry crop under field conditions with respect to the chemical properties and fruit external color rates.

\section{Materials and Methods}

The field experiment was conducted at the Vegetable Crops Sector, at Universidade Federal de Lavras (UFLA), Lavras, Minas Gerais State, Brazil, at an average altitude of $910 \mathrm{~m}, 21^{\circ} 1^{\prime}$ ' $\mathrm{S}$ of latitude and $45^{\circ} 00^{\prime} \mathrm{W}$ Gr of longitude. The experiment was installed on a dystroferric Red Latossol (EMBRAPA, 1999), which has the following characteristics: $\mathrm{pH}$ in water (6.9); $\mathrm{P}(36.8$ $\left.\mathrm{mg} \mathrm{dm}{ }^{-3}\right) ; \mathrm{K}\left(162 \mathrm{mg} \mathrm{dm}^{-3}\right) ; \mathrm{Ca}\left(39 \mathrm{mmol}_{\mathrm{c}} \mathrm{dm}^{-3}\right)$; $\mathrm{Mg}\left(4 \mathrm{mmol}_{\mathrm{c}} \mathrm{dm}^{-3}\right) ; \mathrm{T}\left(73 \mathrm{mmol}_{\mathrm{c}} \mathrm{dm}^{-3}\right) ; \mathrm{V}(64.4 \%)$; Organic matter $\left(22 \mathrm{~g} \mathrm{~kg}^{-1}\right) ; \mathrm{S}\left(6.2 \mathrm{mg} \mathrm{dm}^{-3}\right)$; $\mathrm{Zn}$ $\left(5.7 \mathrm{mg} \mathrm{dm}{ }^{-3}\right) ; \mathrm{Fe}\left(36.3 \mathrm{mg} \mathrm{dm}^{-3}\right) ; \mathrm{Mn}(17.8 \mathrm{mg}$ $\left.\mathrm{dm}^{-3}\right) ; \mathrm{Cu}\left(6.6 \mathrm{mg} \mathrm{dm}^{-3}\right) ; \mathrm{B}\left(0.5 \mathrm{mg} \mathrm{dm}^{-3}\right)$; Sand $\left(150 \mathrm{~g} \mathrm{~kg}^{-1}\right)$; Silt $\left(370 \mathrm{~g} \mathrm{~kg}^{-1}\right)$; Clay $\left(480 \mathrm{~g} \mathrm{~kg}^{-1}\right)$.

We evaluated four doses of $\mathrm{N}(100,200,300$ and $\left.400 \mathrm{~kg} \mathrm{ha}^{-1}\right)$ and four doses of $\mathrm{K}_{2} \mathrm{O}(150,300$, 450 and $600 \mathrm{~kg} \mathrm{ha}^{-1}$ ), applied through fertigation. The nitrogen and $\mathrm{K}_{2} \mathrm{O}$ sources used were urea (45\% $\mathrm{N})$ and potassium chloride $\left(60 \% \mathrm{~K}_{2} \mathrm{O}\right)$, respectively.

Treatments were arranged in a $4 \times 4$ factorial scheme using a randomized blocks experimental design, three times replicated. The plots, with $1.88 \mathrm{~m}^{2}$, were composed of four rows with five plants each. The spacing used was $0.30 \times 0.30 \mathrm{~m}$. Plants from the ends of the lines were used as boundary, and the useful area comprised of 12 plants of central portion. The beds were covered with polyethylene mulching double-sided, being white top and bottom black, with $25 \mu \mathrm{m}$ of thickness, treated with anti-UV additive. Bare root seedlings of cultivar Aromas imported from Chile, were used.

Fertigations were performed with an injection pump fertilizer, TMB WP-10 model, with a maximum capacity of injection of $60 \mathrm{~L} \mathrm{hour}^{-1}$. Considering an average cycle of culture of 240 days after transplantation, the fertigation was carried out weekly. In the first nine weeks $35 \%$ of the nitrogen dose and $25 \%$ of the potassium dose were applied. Between the $10^{\text {th }}$ and $34^{\text {th }}$ weeks the remaining doses were applied.

In the period of increased fruit production, samples were collected from each treatment for laboratory testing. Measurements were performed at the Laboratory of Fruits and Vegetables Postharvest in the Department of Food Science - UFLA. Initially, the samples were washed and sanitized. Then, the color determinations were performed in ten different points of the surface of strawberries, using a Minolta Colorimeter Model CR-400, with determination by CIE L* $a^{*} b^{*}$ mode, evaluating the indices $\mathrm{L}^{*}$ and $\mathrm{a}^{*}$. The $\mathrm{L}^{*}$ coordinate represents how light or dark a sample is, with values ranging from zero (solid black) to 100 (pure white) and $\mathrm{a}^{*}$ coordinate can assume values from -100 to +100 , where the extremes correspond to green and red colors, respectively.

After this analysis, five grams of each sample were collected and homogenized with $45 \mathrm{ml}$ of distilled water using a polytron. The homogenate was filtered in organza fabric, the filtrate was used for the following determinations. A pHmeter Tecnal (Tec 3 MP) was utilized to determinate the 
$\mathrm{pH}$ according to AOAC methodology (1992). Total soluble solids were obtained with a digital refractometer ATAGO PR-100 Palette, with automatic temperature adjustment, according to AOAC (1992). Finally, titratable total acidity was determined by Instituto Adolfo Lutz's standard procedures (1985). The ratio of total soluble solids to titratable total acidity was calculated.

All data were subjected to variance analysis using the statistical program Sisvar (Ferreira, 2003), through which regression equations were adjusted.

\section{Results and Discussion}

Analyses of variance values for the content of soluble solids, titratable total acidity, the relationship between total soluble solids and titratable total acidity and the $\mathrm{a}^{*}$ index revealed that these characteristics were significantly influenced by both, the nitrogen and potassium doses, as well as the interaction between the two factors. On the other hand $\mathrm{pH}$ was not affected by levels of potassium alone, but was influenced by the nitrogen and the interaction between the levels of potassium and nitrogen. The $\mathrm{L}^{*}$ index was affected only by the interaction between factors (Table 1 ).

Table 2 shows the breakdown of potassium levels within each level of nitrogen, as well as their respective regression equations, when there were appropriate polynomial significance and fit.

In this work, the higher fruit $\mathrm{pH}$ was 3.76 , a value obtained when $100 \mathrm{~kg} \mathrm{ha}^{-1}$ of $\mathrm{N}$ and $150 \mathrm{~kg} \mathrm{ha}^{-1}$ of $\mathrm{K}_{2} \mathrm{O}$ were applied. Using this fertilization management, the strawberries are adequate to fresh consumption, because the determination of $\mathrm{pH}$ of fruits is important in defining the purpose of the same. Strawberries with more acidic $\mathrm{pH}$, lower than 3.5, are proper for industrial use, while the consumer market of fresh strawberries prefers less acidic fruits. For the cultivar Aromas, Flores Castillano et al. (2008) observed mean $\mathrm{pH}$ of 3.3 at fruits harvest. Approximate values of fruit $\mathrm{pH}$ were verified by Antunes et al. (2010), studying other strawberry cultivars in different cultivation sites.

Fresh strawberry consumption fruits should have a total soluble solids of $7^{\circ}$ Brix or higher, according to Manning (1996). This is achieved with the application of 200 and $400 \mathrm{~kg} \mathrm{ha}^{-1}$ of nitrogen, independent of the potassium level applied. Using the generated equations the maximum levels of total soluble solids of 8.25 and $9.29^{\circ}$ Brix were calculated for $100 \mathrm{~kg} \mathrm{ha}^{-1}$ nitrogen with $366.67 \mathrm{~kg} \mathrm{ha}^{-1}$ of $\mathrm{K}_{2} \mathrm{O}$ and $300 \mathrm{~kg} \mathrm{ha}^{-1}$ nitrogen with $335 \mathrm{~kg} \mathrm{ha}^{-1}$ of $\mathrm{K}_{2} \mathrm{O}$, respectively. The results are above the acceptable minimum implying that the fruits are suitable for the fresh market. The soluble solids obtained in this study do not differ from other studies in the literature that such analysis were performed in the harvest day (Vargas et al., 2006; Bodelón et al., 2010).

According to Manning (1996), in order to be considered for fresh consumption, strawberries should have titratable acidity of $0.8 \%$ or lower. In the conditions in which our experiment was conducted, it is noted that the management of the doses in which the acidity is closer to the maximum value acceptable was with the application of $200 \mathrm{~kg} \mathrm{ha}^{-1}$ of nitrogen and $344.50 \mathrm{~kg} \mathrm{ha}^{-1}$ of $\mathrm{K}_{2} \mathrm{O}$. Vargas et al. (2006) studied the quality of stored cultivar Camarosa strawberries, also found average titratable acidity of $0.87 \%$ on the harvest day.

Table 1. Summary of variance analysis for $\mathrm{pH}$, total soluble solids (TSS), titratable acidity (TA), total soluble solids and titratable acidity (TSS / TA) and external color index in fruits of strawberry due to fertigation of nitrogen and potassium. UFLA, Lavras, MG, 2011.

\begin{tabular}{lccccccc}
\hline \multirow{2}{*}{ VF } & DF & \multicolumn{6}{c}{ Medium Squares } \\
\cline { 3 - 7 } & & $\mathrm{pH}$ & $\mathrm{TSS}\left({ }^{\circ} \mathrm{Brix}\right)$ & $\mathrm{TA}(\%)$ & \multicolumn{1}{c}{ TSS/TA } & $\mathrm{L}^{*}$ & $\mathrm{a}^{*}$ \\
\hline N Doses & 3 & $0.1622^{*}$ & $2.0900^{*}$ & $0.1794^{*}$ & $8.8489^{*}$ & 1.1410 & $19.4672^{*}$ \\
$\mathrm{~K}_{2} \mathrm{O}$ Doses & 3 & 0.0547 & $6.7300^{*}$ & $0.2374^{*}$ & $11.9161^{*}$ & 0.8339 & $3.7141^{*}$ \\
$\mathrm{~N} \mathrm{x} \mathrm{K}_{2} \mathrm{O}$ & 9 & $0.0969^{*}$ & $4.8167^{*}$ & $0.0837^{*}$ & $5.7455^{*}$ & $3.4921^{*}$ & $8.4452^{*}$ \\
Block & 2 & 0.0133 & 0.0300 & 0.0081 & 0.0472 & 0.0639 & 0.0898 \\
Residue & 30 & 0.0217 & 0.6460 & 0.0103 & 0.7592 & 0.7103 & 0.5434 \\
\hline VC $(\%)$ & & 4.05 & 10.08 & 8.91 & 12.00 & 2.74 & 4.42 \\
\hline General averages & & 3.6410 & 7.9750 & 1.1396 & 7.2631 & 30.7771 & 16.6700 \\
\hline
\end{tabular}

* Significant at $5 \%$ probability by the $\mathrm{F}$ test $(\mathrm{P}<0.05)$. 
Table 2. Regression equations for $\mathrm{pH}$, total soluble solids (TSS), titratable acidity (TA), total soluble solids and titratable acidity (TSS / TA) and external color index in fruits of strawberry due to the fertigation of nitrogen and potassium.

UFLA, Lavras, MG, 2011.

\begin{tabular}{|c|c|c|}
\hline Treatments & Regression Equations & $\mathrm{R}^{2}$ \\
\hline $\begin{array}{l}\mathrm{K}_{2} \mathrm{O}: 100 \mathrm{~kg} \mathrm{ha}^{-1} \mathrm{~N} \\
\mathrm{~K}_{2} \mathrm{O}: 200 \mathrm{~kg} \mathrm{ha}^{-1} \mathrm{~N} \\
\mathrm{~K}_{2} \mathrm{O}: 300 \mathrm{~kg} \mathrm{ha}^{-1} \mathrm{~N} \\
\mathrm{~K}_{2} \mathrm{O}: 400 \mathrm{~kg} \mathrm{ha}^{-1} \mathrm{~N}\end{array}$ & $\begin{array}{l}\mathrm{y}=4.4167-0.0054 \mathrm{x}+0.00001 \mathrm{x}^{2} \\
\text { Unadjusted } \\
\mathrm{y}_{\text {medium }}=3.60 \\
\mathrm{y}_{\text {medium }}=3.67\end{array}$ & $0.91^{*}$ \\
\hline $\begin{array}{l}\mathrm{K}_{2} \mathrm{O}: 100 \mathrm{~kg} \mathrm{ha}^{-1} \mathrm{~N} \\
\mathrm{~K}_{2} \mathrm{O}: 200 \mathrm{~kg} \mathrm{ha}^{-1} \mathrm{~N} \\
\mathrm{~K}_{2} \mathrm{O}: 300 \mathrm{~kg} \mathrm{ha}^{-1} \mathrm{~N} \\
\mathrm{~K}_{2} \mathrm{O}: 400 \mathrm{~kg} \mathrm{ha}^{-1} \mathrm{~N}\end{array}$ & $\begin{array}{l}\mathrm{y}=4.3500+0.0213 \mathrm{x}-0.00003 \mathrm{x}^{2} \\
\mathrm{y}_{\text {medium }}=8.45 \\
\mathrm{y}=4.8000+0.0268 \mathrm{x}-0.00004 \mathrm{x}^{2} \\
\mathrm{y}_{\text {medium }}=7.90\end{array}$ & $0.47^{*}$ \\
\hline $\begin{array}{l}\mathrm{K}_{2} \mathrm{O}: 100 \mathrm{~kg} \mathrm{ha}^{-1} \mathrm{~N} \\
\mathrm{~K}_{2} \mathrm{O}: 200 \mathrm{~kg} \mathrm{ha}^{-1} \mathrm{~N} \\
\mathrm{~K}_{2} \mathrm{O}: 300 \mathrm{~kg} \mathrm{ha}^{-1} \mathrm{~N} \\
\mathrm{~K}_{2} \mathrm{O}: 400 \mathrm{~kg} \mathrm{ha}^{-1} \mathrm{~N}\end{array}$ & $\begin{array}{l}y=1.8525-0.0033 x+0.000004 x^{2} \\
y=1.2300-0.0021 x+0.000003 x^{2} \\
y=0.7150+0.0029 x-0.000004 x^{2} \\
y=2.2625-0.0062 x+0.00001 x^{2}\end{array}$ & $\begin{array}{l}0.31^{*} \\
0.46^{*} \\
0.31^{*} \\
0.99^{*}\end{array}$ \\
\hline $\begin{array}{l}\mathrm{K}_{2} \mathrm{O}: 100 \mathrm{~kg} \mathrm{ha}^{-1} \mathrm{~N} \\
\mathrm{~K}_{2} \mathrm{O}: 200 \mathrm{~kg} \mathrm{ha}^{-1} \mathrm{~N} \\
\mathrm{~K}_{2} \mathrm{O}: 300 \mathrm{~kg} \mathrm{ha}^{-1} \mathrm{~N} \\
\mathrm{~K}_{2} \mathrm{O}: 400 \mathrm{~kg} \mathrm{ha}^{-1} \mathrm{~N}\end{array}$ & $\begin{array}{l}y=0.5300+0.0332 x-0.0004 x^{2} \\
y=3.3633+0.0384 x-0.00005 x^{2} \\
y=8.8200-0.0045 x \\
y=1.7592+0.0320 x-0.00004 x^{2}\end{array}$ & $\begin{array}{l}0.37^{*} \\
0.78^{*} \\
0.75^{*} \\
0.99^{*}\end{array}$ \\
\hline $\begin{array}{l}\mathrm{K}_{2} \mathrm{O}: 100 \mathrm{~kg} \mathrm{ha}^{-1} \mathrm{~N} \\
\mathrm{~K}_{2} \mathrm{O}: 200 \mathrm{~kg} \mathrm{ha}^{-1} \mathrm{~N} \\
\mathrm{~K}_{2} \mathrm{O}: 300 \mathrm{~kg} \mathrm{ha}^{-1} \mathrm{~N} \\
\mathrm{~K}_{2} \mathrm{O}: 400 \mathrm{~kg} \mathrm{ha}^{-1} \mathrm{~N}\end{array}$ & $\begin{array}{l}\mathrm{y}_{\text {medium }}=30.90 \\
\mathrm{y}_{\text {medium }}=30.73 \\
\mathrm{y}=26.4383+0.0229 \mathrm{x}-0.00003 \mathrm{x}^{2} \\
\mathrm{y}=36.4108-0.0349 \mathrm{x}+0.00005 \mathrm{x}^{2}\end{array}$ & $\begin{array}{l}0.55^{*} \\
0.79^{*}\end{array}$ \\
\hline $\begin{array}{l}\mathrm{K}_{2} \mathrm{O}: 100 \mathrm{~kg} \mathrm{ha}^{-1} \mathrm{~N} \\
\mathrm{~K}_{2} \mathrm{O}: 200 \mathrm{~kg} \mathrm{ha}^{-1} \mathrm{~N} \\
\mathrm{~K}_{2} \mathrm{O}: 300 \mathrm{~kg} \mathrm{ha}^{-1} \mathrm{~N} \\
\mathrm{~K}_{2} \mathrm{O}: 400 \mathrm{~kg} \mathrm{ha}^{-1} \mathrm{~N}\end{array}$ & $\begin{array}{l}\mathrm{y}=15.3525+0.0277 \mathrm{x}-0.00005 \mathrm{x}^{2} \\
\mathrm{y}=8.3225+0.0382 \mathrm{x}-0.00005 \mathrm{x}^{2} \\
\mathrm{y}=15.2783+0.0039 \mathrm{x} \\
\mathrm{y}_{\text {medium }}=17.87\end{array}$ & $\begin{array}{l}0.90^{*} \\
0.85^{*} \\
0.94^{*}\end{array}$ \\
\hline
\end{tabular}

* Significant at $5 \%$ probability by the $\mathrm{F}$ test $(\mathrm{P}<0.05)$.

Valero \& Altisent (1998) explain that the sugars and acids ratio evolves inversely with their respective concentrations, while the sugar content increases with fruit maturation, acid decreases. This parameter is very significant, because it indicates the balance degree of fruit flavor. The ratio of soluble solids and titratable acidity is responsible for a part of the fruit flavor. This means that in order that a fruit have good flavor, the quantities of acid and sugar should maintain a certain proportion (Berbari et al., 1998). Considering this, the application of 200 $\mathrm{kg} \mathrm{ha}^{-1}$ of nitrogen with $349.39 \mathrm{~kg} \mathrm{ha}^{-1}$ of $\mathrm{K}_{2} \mathrm{O}$, showed better results among the applied doses (10.08). Flores Cantillano et al. (2008), working with three strawberry cultivars in Southern Brazil, found that the cultivar Aromas had total soluble solids and total acidity ratio of 9.52 at the time of harvest, slightly lower than our best result.

In the evaluation of fruits external color, we observed the minimum value of the index $\mathrm{L}^{*}$ of 29.26 , with the application of $300 \mathrm{~kg} \mathrm{ha}^{-1}$ of nitrogen and $150 \mathrm{~kg} \mathrm{ha}^{-1}$ of $\mathrm{K}_{2} \mathrm{O}$, and maximum value of 32.21 in management of $400 \mathrm{~kg} \mathrm{ha}^{-1}$ of nitrogen and $150 \mathrm{~kg} \mathrm{ha}^{-1}$ of $\mathrm{K}_{2} \mathrm{O}$. These values for the parameter $\mathrm{L}^{*}$ are similar to the ones found in the literature, characteristic of fresh strawberries. Bodelón et al. (2010) found values between 28.52 and 37.06 for this external color parameter for the 
cultivar Camarosa. Reis et al. (2008) working with Oso Grande cultivar strawberries observed mean value of 29.14 for the parameter L*.

In the index $\mathrm{a}^{*}$, it was found that the application of $100 \mathrm{~kg} \mathrm{ha}^{-1}$ of nitrogen resulted in the higher value, 19.13, when $272.04 \mathrm{~kg} \mathrm{ha}^{-1}$ of $\mathrm{K}_{2} \mathrm{O}$ was applied. Figueiredo et al. (2010), studying the application of silicon in Oso Grande strawberries cultivar, found that the fruits of the control group (without the application of this nutrient) showed values around 34 in the $\mathrm{a}^{*}$ color property. This average was higher than the ones found in our work but it is known that the color of each cultivar is a genetic characteristic that is influenced by climatic and cultural factors (Calegaro et al., 2002).

\section{Conclusions}

The chemical properties and external color rates of strawberry fruits cultivar Aromas are sensible to nitrogen and potassium doses applied via fertigation technique, varying according to the studied property.

\section{Acknowledgements}

CNPq-National Council for Scientific and Technological Development, for the grant of scholarship to obtain the title of Ph.D in Agronomy / Soil Science to the first author.

\section{Literature Cited}

Antunes, L.E.C.; Ristow, N.C.; Kroslow, A.C.R.; Carpenedo,

S.; Reisser Júnior, C.

2010. Yield and quality of strawberry cultivars. Horticultura Brasileira, Brasília. 28: 222-226.

AOAC - Association of Official Analytical Chemistry

1992. Official methods of analysis of the Association of Agricultural Chemists. 12 ed. Washington: AOAC, 1015 p.

Berbari, S.A.G.; Nogueira, J.N.; Campos, S.D.S.

1998. Efeito de diferentes tratamentos pré-congelamento sobre a qualidade do morango var. Chandler congelado. Ciência e Tecnologia de Alimentos, Campinas. 18: 82-86.

Bodelón, O.G.; Blanch, M.; Sanchez-Ballesta, M.T.; Escribano, M.I.; Merodio, C.

2010. The effects of high $\mathrm{CO}_{2}$ levels on anthocyanin composition, antioxidant activity and soluble sugar content of strawberries stored at low non-freezing temperature. Food Chemistry, Barking, 122: 673-678.

Brackmann, A.; Freitas, S.T.; Mello, A.M.; Neuwald, D.A. 2002. Efeito da temperatura de armazenamento sobre a qualidade do morango cultivar 'Oso Grande'. Revista Brasileira de Agrociência, Pelotas. 8 (1): 77-78.

Calegaro, J.M.; Pezzi, E.; Bender, R.J.

2002. Utilização de atmosfera modificada na conservação de morangos em pós-colheita. Pesquisa Agropecuária Brasileira, Brasília. 37: 1-6.

Cárdenas-Navarro, R.; Sánchez-Yañez, J.M.; Farias-Rodríguez,

R.; Peña-Cabriales, J.J.

2004 Los aportes de nitrógeno en la agricultura. Revista Chapingo Serie Horticultura. 10 (2): 173-178.

Chitarra, M.I.F.; Chitarra, A.B.

2005. Pós-colheita de frutos e hortaliças: fisiologia e manuseio. Lavras: UFLA, 785 p.

EMBRAPA

1999. Sistema brasileiro de classificação de solos. Rio de FAO

Janeiro: Embrapa Solos, 412 p.

2010. FAOSTAT: Statistical of strawberry production in world, disponível em: <http://faostat.fao.org/site/567/default. aspx\#ancor>, consultado em 15 jul. 2011.
Ferreira, D.F.

2003. SISVAR software: versão 4.6. Lavras: UFLA/ DEX.

Figueiredo, F.C.; Botrel, P.P.; Teixeira, C.P.; Petrazzini, L.L.; Locarno, M.; Carvalho, J.G.

2010. Pulverização foliar e fertirrigação com silício nos atributos físico-químicos de qualidade e índices de coloração do morango. Ciência e Agrotecnologia, Lavras. 34: 1306-1311.

Flores Cantillano, R.F. (Ed.).

2003. Morango: Pós-colheita. Embrapa Clima Temperado. Pelotas: Embrapa Clima Temperado; Brasília: Embrapa Informação Tecnológica. 28 p. (Frutas do Brasil, 42).

Flores Cantillano, R.F.; Castañeda, L.M.F.; Treptow, R.O.;

Schunemann, A.P.P.

2008. Qualidade físico-química e sensorial de cultivares de morango durante o armazenamento refrigerado. Pelotas: Embrapa Clima Temperado, 30 p. Boletim de Pesquisa e Desenvolvimento, 75.

Hagin, J.; Sneh, M.; Lowengart-Aycicegi, A.

2002. Fertigation: Fertilization through irrigation. Basel: IPI. $81 \mathrm{p}$.

Instituto Adolfo Lutz

1985. Normas analíticas, métodos químicos e físicos para a análise de alimentos. 3 ed., v. 1. São Paulo: Instituto Adolfo Lutz, $533 \mathrm{p}$.

Kafkafi, U.; Tarchitzky, J.

2011. Fertigation: a tool for efficient fertilizer and water management. Paris: IFA/IPI. $141 \mathrm{p}$.

Lima, L.C.O.

1999. Qualidade, colheita e manuseio pós-colheita de frutos de morangueiro. Informe Agropecuário. Belo Horizonte: EPAMIG, 20 (198): 80-83.

Manning, K.

1996. Soft fruits. In: Seymour, G.B.; Taylor, J.E.; Tucker, G.A. (Eds.). Biochemistry of fruit ripening. London: Chapman \& Hall. p. 347-377.

Nestby, R.; Ieten, F.; Pivot, D.; Raynal Lacroix, C.; Tagliavini, M.; Evenhuis, B.

2004. Influence of mineral nutrients on strawberry fruit quality and their accumulation in plant organs. Acta Horticulturae. 649: 201-205. 
Recamales, A.F.; Medina, J.L.; Hernanz, D.

2007. Physicochemical characteristics and mineral content of strawberries grown in soil and soilless system. Journal of Food Quality. 30: 837-853.

Reis, K.C.; Siqueira, H.H.; Alves, A.P.; Silva, J.D.; Lima, L.C.O. 2008. Efeitos de diferentes sanificantes sobre a qualidade de morango cv. Oso Grande. Ciência e Agrotecnologia, Lavras. 32: 196-202.

Valero, C.; Altisent, M.R.

1998. Equipos de medida de calidad organoléptica en frutas. Fruticultura Profesional, Madri. 2: 38-45.
Vargas, M.; Albors, A.; Chiralt, A.; González-Martínez, C. 2006. Quality of cold-stored strawberries as affected by chitosan-oleic acid edible coatings. Postharvest Biology and Technology, Amsterdam. 41: 164-171.

Vázquez-Gálvez, G.; Cárdenas-Navarro, R.; Lobit, P. 2008. Efecto del Nitrógeno sobre el crecimiento y rendimiento de fresa regada por goteo y gravedad. Agricultura Técnica en México. 34 (2): 235-241. 